\title{
THE HOUSEWIFE'S BATTLE ON THE HOME FRONT: WOMEN IN WORLD WAR II ADVERTISEMENTS
}

\author{
By Caroline Cornell
}

A 1944 advertisement for Swift's Beef in Good Housekeeping boldly proclaimed, "Her SEVEN jobs all help win the war!" The seven "jobs" were tasks that the Swift Company-as well as the U.S. governmentbelieved that women on the home front should perform in order to aid their country during World War II. Among the tasks promoted by the advertisement were rationing, the growing of "victory gardens," salvaging and recycling, and the purchasing of war bonds. Though the advertisement claimed that these responsibilities "all help win the war," each of the jobs described centered around household activities. Despite the fact that the Swift's Beef advertisement gave agency to American women by claiming they could impact the success of the war, it still emphasized their femininity by giving primacy to the roles of wife and mother and by utilizing an image of a Red Cross volunteer as their "war worker," not a woman working in the war industry.

\footnotetext{
1 "Her Seven Jobs Help Win the War," Swift's Brands of Beef, Advertisement, Good Housekeeping, January 1944, 15.
} 
The Good Housekeeping advertisement exemplifies how World War II advertisements not only frequently targeted American women to aid the war effort, but also placed the responsibility of obtaining victory in the hands of the housewife. To some, this may appear as a surprising contrast to the popular image of "Rosie the Riveter" that tends to dominate modern-day conceptions of the representation of American women during World War II. In this paper, however, I will argue that, although women were entering the workforce in large numbers during World War II, the U.S. government and the advertising industry believed American housewives to be as vital to the war's success as "Rosie the Riveter." While numerous scholars argue that housewives were a major contributing factor to America's victory in World War II, they often neglect the ways in which advertisements largely ignored the roles of working women during the war. World War II era advertisements and posters glorified and elevated the status of the housewife, which, I will argue, encouraged women to remain in a sphere of domesticity during, as well as after, the war.

To fully comprehend the depiction of American women in advertisements, it is important to look at advertisements created by both the U.S. government and private American companies during the war. T.J. Jackson Lears has used the term "hegemony" to describe the ways in which a particular ruling class relies on various intellectual groups to establish a society's conventional wisdom. ${ }^{2}$ This relationship was evident during World War II when the attacks on Pearl Harbor not only caused the U.S. government to enter World War II, but also to enter a partnership with the advertising industry. This intimate relationship is apparent in the creation of the War Advertising Council in 1942, wherein the government and private industry began a string of advertisements aimed at directly shaping the opinion of the American

2 T.J. Jackson Lears, "From Salvation to Self-Realization: Advertising and the Therapeutic Roots of the Consumer Culture, 1880-1930," in The Culture of Consumption: Critical Essays in American History, 1880-1980, ed. Richard Wightman Fox and T.J. Jackson Lears, 3-38 (New York: Pantheon Books, 1983), 5. The term "hegemony" was originally created by Antonio Gramsci. 
public. ${ }^{3}$ Lears's observations on the "therapeutic ethos" are also applicable to World War II advertisements as advertisers began to make greater use of therapeutic and psychological techniques to attract the attention of consumers and sell their products or ideas. ${ }^{4}$ Because the war was an extremely emotional time for families at home, it was easy for advertisers to utilize these tactics.

While the U.S. government used the advertising industry as a vehicle for the dispersion of messages to the masses, advertisers also had numerous motives in entering a partnership with the government. In exploring the relationships between the U.S. government and the advertising industry throughout World War II, both Robert Griffith and Mark Leff have argued that the advertising industry used the war as a means to lift the industry from its dire financial state. While Griffith highlights the immense profit reaped by advertisers during the war, Leff goes further and labels the industry's motivations as selfish. Moreover, Leff contends that such self-interest was representative of the general American population. ${ }^{5}$ He claims that because Americans were distanced from the physical conflict of the wars in Europe and the Pacific, the government had to work harder to convince Americans that they ought to sacrifice goods and luxuries to aid the war effort. ${ }^{6}$ In this sense, the creation of the War Advertising Council was as essential for the struggling advertising industry as it was for the Office of War Information, which relied on influential advertisements to sway public opinion. Understanding these "selfish motives" provides insight into the underlying messages of many World War II advertisements and their intended audience-which was, in many cases, women.

Though both Griffith and Leff recognize conflicting motives within the creation of advertisements, they ignore how the government, as well as the advertising industry, targeted the American housewife. They also fail to recognize and analyze why household advertisements

\footnotetext{
${ }^{3}$ Robert Griffith, "The Selling of America: The Advertising Council and American Politics, 1942-1960," The Business History Review 57, no. 3 (Autumn 1983): 390.

${ }^{4}$ Lears, 21.

${ }^{5}$ Griffith, 391.

${ }^{6}$ Mark Leff, "The Politics of Sacrifice on the American Home-Front in World War II," The Journal of American History 77, no. 4 (March 1991): 1310-1314.
} 
peaked during the war years, an observation duly noted by Russell Belk and Richard Pollay. ${ }^{7}$ That domestic-centered advertisements peaked during the war years suggests not only that the government and the advertising industry were deliberately targeting a particular demographic, but also suggests that they were consciously emphasizing that women should return to their "proper places" at home at the conclusion of the war.

The emphasis on encouraging women to remain at home is evident in advertisements concerning rationing policies. Such advertisements portrayed the housewife as critical to the success of rationing policies and simultaneously encouraged women to continue with their domestic duties by exalting their daily tasks as critical to the war's success. Advertisements not only called on women to buy groceries according to rationing policies, but also included ways that women could cope with rationing and product scarcity. Rationing coupons became a common accessory when women went grocery shopping, and housewives had to learn how to alter their favorite recipes due to the scarcity of certain ingredients. Traditionally imported goods, including sugar, spices, coffee, and tin (used for canned food), became extremely hard to acquire since crops were often ravaged by war or difficult to transport due to fuel shortages. ${ }^{8}$ Advertisements also called on American women to help enforce rationing policies and recognized that because females made up the majority of the consumer population buying groceries, they had a large amount of influence on whether or not the policies were successful.

John D. Morris, a journalist for The New York Times, stressed the importance of female consumers and urged them to use their influence to directly aid the government with rationing. As a congressional affairs correspondent, Morris called on housewives to help the government end the problem of black markets and counterfeit coupons, which had become a negative consequence of the food rationing policies and were

${ }^{7}$ Russell W. Belk and Richard W. Pollay, "Images of Ourselves: The Good Life in Twentieth Century Advertising," The Journal of Consumer Research 11, no. 4 (March 1985): 890.

${ }^{8}$ Doris Weatherford, American Women and World War II (New York: Facts on File, 1990), 200. 
harming the war economy. While discussing meat rationing in one of his articles, Morris stated "enforcement will be aided if a housewife reports to her ration board that her neighbor has plenty of meat, while she herself is limited to, say, two pounds a week." This direct call to American housewives demonstrates the belief that cooperation from American housewives was essential to the success of rationing policies. Although Morris's call to action indicates a suspicion that some women were abusing rationing policies, it also encourages other housewives to combat the criminal acts by using the simple tasks that they already performed before the war-acts like grocery shopping and snooping out their neighbors. This trust in American women added an element of respect and admiration to their daily routine, and showed the belief that they could not only be relied on to carry out rationing policies, but could also be necessary allies for the battle on the home front.

Instead of emphasizing the national importance of implementing rationing policies, some American companies chose to manipulate existing frustrations that women had concerning rationing in order to gain a profit. Rationing had forced many women to alter their favorite recipes to accommodate the lack of certain ingredients. In response to this, numerous cookbooks emerged advertising recipes that suited limited ingredients—-such as "sugarless recipes"-while continuing to ensure quality, well-balanced meals. A 1940s cookbook compiled by Marion White, for example, was described as "a 'must' for every American housewife," and promised female consumers that they would "never worry about sugar rationing with this thrilling book which tells you how to make tempting, tasty, delicious desserts without sugar." ${ }^{10}$ This shows how the advertisers and the cookbook company automatically connected the task of rationing with housewives, and implied that one was an inadequate wife and mother if they did not adhere to their patriotic duties. Not only did cookbooks like Marion White's serve as an example of how companies used wartime conditions to sell their prod-

9 John D. Morris, "Policing of the Food Front up to Housewife in the End," The New York Times, February 28, 1943.

${ }^{10}$ Sweets without Sugar cookbook, M.S. Mill Co., Inc., Advertisement, The New York Times, June 10, 1942.The cited advertisement originally appeared on page 19. 
ucts, but it also epitomizes the ways in which housewives were specifically targeted and believed to be the leading force in policies relating to consumption.

Some food companies opted for a more indirect approach to advertising when dealing with rationing by including recipes that were suited for the war environment. A 1944 Swift's Beef advertisement provides an example of this strategy. The advertisement included a pot roast recipe with a statement that urged women to pay close attention while cooking to preserve the nutritional value of their food and make the most of their meat, which was hard to come by due to food shortages. ${ }^{11}$ The advertisement recognized that housewives were significantly affected by rationing policies and thus tried to help them maintain their supremacy in the kitchen despite the resulting hardships of the period. It also links the recipe with the product's name in order to maintain brand recognition both during and after the war. By helping consumers deal with restrictions on food products, companies were also able to create a positive image for themselves when housewives were able to purchase their products again.

The government also relied on advertisements in order to promote solutions to the drastic decrease in the amount of available food as a consequence of the war, particularly shortages of produce. "Victory gardens" were commonly advertised as an answer to the problems brought on by rationing and were presented as both a way for women to help feed their own families and a means to aid the government by decreasing the amount of dependence on American farmers. Women were urged to grow their own vegetables-about 20 million Americans eventually planted victory gardens and community gardens were set up in some towns using available vacant plots of land. ${ }^{12}$ Advertisements created by the War Advertising Council urged Americans, mainly

\footnotetext{
11 "Her Seven Jobs Help Win the War." Swift's Brands of Beef Advertisement.

${ }^{12}$ Harvard Sitkoff, "The American Home Front," in Produce and Conserve, Share and Play Square: The Grocer and the Consumer on the Home-Front Battlefield during World War II, ed. Barbara McLean Ward, 36-56 (Hanover, NH: University Press of New England, 1994), 44; Mary Drake McFeely, "The War in the Kitchen," in Produce and Conserve, Share and Play Square: The Grocer and the Consumer on the Home-Front Battlefield during World War II, 104-116 (see above), 110
} 
women, to not only grow their own vegetables, but to can their produce to save for the winter.

One such advertisement featured a mother and daughter canning the vegetables from their garden. The girl is pictured asking her mother, "We'll have lots to eat this winter, won't we mother?" The mother is featured smiling and at the bottom of the page the advertisement states, "Grow your own, can your own."13 The advertisement employs a therapeutic ethos by picturing a mother and daughter and by delivering the message that if women grow their own victory gardens, they will be able to support their families with a sufficient amount of vegetables that may not be available if they were to rely solely on American farmers. The daughter toys with the emotions of American women by urging them to view victory gardens as a necessity to protect their family from going hungry, and thus, by encouraging them to tend their gardens, the advertisement is able to advocate that women remain at home.

Recognizing that American women desired a quick end to the war, advertisements encouraging women to salvage and recycle materials sought to establish a direct relationship between the home and the battlefield, that would make women more receptive to the idea that their daily actions affected the outcome of the war. Magazine articles "called out" American women and argued that they were the reasons why the battle on the home front was failing. An article in Life stated that women had to help the country by conserving fats and tin, and attacked them by saying, "Just remember that everything your family consumes retards the war effort." ${ }^{14}$ Though the article specifically relates to the failures of domestic consumption policies, the attribution of blame relative to the war effort recognizes housewives as the predominant "fighting force" at home.

Not only were women recognized as "fighters" at home, scholars have argued that advertisements and war campaigns caused a complete

${ }^{13}$ Al Parker, "We'll Have Lots to Eat This Winter, Won't We, Mother?" (Poster, U.S. Office of War Information, 1943) The Smithsonian Institute's National Museum of History, http://americanhistory.si.edu/victory/victory5.htm (accessed November 23, 2009).

14 "What Women Can Do: Think War, Buy Little, Maintain Our Ideals," Life, September 28, 1942, 32. 
militarization of the household. Typical household chores were turned into "weapons of war," which is especially evident with political posters urging women to aid salvaging and recycling efforts. ${ }^{15}$ A poster created by the War Production Board in 1941, which encouraged citizens to salvage their tin cans, highlighted how they believed American women had a direct impact on the success of the war overseas. It boldly stated, "Save Your Cans: Help Pass the Ammunition," and lists the four steps that one must take to "Prepare your tin cans for war." The poster pictures a woman's arm holding a line of tin cans that eventually turn into bullets for a fighting soldier's machine gun. ${ }^{16}$ This poster illustrates how the government used advertisements and posters to convince American women that their salvaging and recycling habits at home directly influenced the fighting occurring in Europe and the Pacific. The argument that the typical household became a direct extension of the battlefields that American soldiers were fighting on helped to add importance to the daily tasks conducted by housewives.

Despite the fact that numerous advertisements assisted in militarizing the role of the housewife, Maureen Honey argues that working women were seen as the bold heroines of the decade. Housewives, according to Honey, were depicted as the symbols of American values and virtues that had to be safeguarded. ${ }^{17}$ Even though both groups of women contributed greatly to the war effort, the housewife was not portrayed to be as passive as Honey claims, especially if her household tasks were viewed as "weapons of war." By portraying these women as directly aiding and partaking in the war effort, advertisers portrayed their contributions from home to be equivalent to those made by women working in the factories and war industry.

Along with increasing the importance of the jobs and duties of American housewives during World War II, advertisements still advo-

15 Terrence H. Witowski, “World War II Poster Campaigns: Preaching Frugality to American Consumers," Journal of Advertising 32, no. 1 (Spring 2003): 74.

${ }^{16}$ McClelland Barclay, "Save Your Cans" (Poster, U.S. War Production Board, 1943) The Ohio Historical Society, http://ohsweb.ohiohistory.org/ohiopix/ Image.cfm?ID=5020 (accessed November 24, 2009).

${ }^{17}$ Maureen Honey, Creating Rosie the Riveter: Class, Gender, and Propaganda during World War II (Amherst: The University of Massachusetts Press, 1984), 131. 
cated that women follow their obligations as wives and mothers. The images commonly remembered today_such as the famous "Rosie the Riveter" image-were certainly present during the war years, but became less visible as the war came to a conclusion. Although Maureen Honey seems to emphasize the image of working women above the housewife during World War II, she does detail this shift in the portrayal of both groups and shows how even advertisements that did focus on the working mother sometimes included statements reiterating the temporality of roles as a working woman. ${ }^{18}$ That advertisers felt the need to state that jobs held by women during the war were purely provisional indicates a dramatic contrast to today's image of female industry workers as wartime "heroines." Indeed, it suggests that advertisers did not fully accept the new roles women occupied and expected post-war society to return to more conservative gender roles.

An advertisement for the Adel Manufacturing Company featured in a 1944 Saturday Evening Post illustrates this emphasis on temporary occupation. In the advertisement, a mother is pictured in overalls leaning on her bike before she leaves for work. Her daughter is pictured in a similar outfit and asks, "Mother, when will you stay home again?" Above the image a statement reads, "Some jubilant day mother will stay home again, doing the job she likes best-making a home for you and daddy....Meanwhile she's learning the vital importance of precision in equipment made by ADEL. In her post-war home she'll want appliances with the same high degree of precision." ${ }^{19}$ Though the advertisement recognizes the importance of the female worker in helping the war effort, it clearly points out that women should return to the home once the war ends. The advertisement also seizes on the emotions of American females, utilizing a therapeutic ethos once again to make it appear that she is harming her children if she does not return to her duties at home and implements particular words that are charged with this sentiment. Phrases like "jubilant day" and "will stay home

18 Ibid., 124.

19 "Mother, when will you stay home again?" Adel Manufacturing Company, Advertisement, in Creating Rosie the Riveter: Class, Gender, and Propaganda during World War II (Amherst: The University of Massachusetts Press, 1984), 125. 
again" suggest that her place in the workforce is only positive because it is temporarily filling an essential void in support of the war and that she should revert to her "housewife occupation" as soon as possible. Though advertisements often pictured working women, and regularly cast them in a positive light, the fact that some advertisements viewed females in the workplace as only a temporary advantage shows that companies were still hesitant for women to abandon their responsibilities at home and enter the work force permanently.

The encouragement found in advertisements for women to remain at home both during and after the war went so far as to urge them to take control of areas in their household that they typically did not manage. Despite the fact that women were not the main contributors to their family's income, they were given the task to budget their family's finances in order to set aside money for purchasing war bonds that directly funded the war abroad. The government created war bonds, modeled on the Liberty Bonds of World War I, as a way for American citizens to help fund the war effort by essentially loaning the government money along with a fixed interest rate. Numerous advertisements targeted women to purchase these war bonds and emphasized that by doing so, they would be doing their part to aid the war effort. This was seen in an advertisement created by the War Advertising Council that outlined the different tasks women could do, which read, "Help bring them back to you-Make yours a victory home!" The advertisement features a home with a blue star hanging in the window (signifying that someone in the family was serving in the military) and states as their last bullet-point that women should save $10 \%$ of their household's income to purchase war bonds..$^{20}$ By having a blue star as the main focus of the advertisement it targets the emotions of numerous American women who had husbands, sons, brothers, or other loved ones fighting in the war. The advertisement seems to claim that, by purchasing war bonds and assisting the war effort, women could help to

${ }^{20}$ Francis Criss, "Help bring them back to you! ...Make yours a Victory Home!" (Poster, U.S. Office of War Information, 1943) The Smithsonian Institute's National Museum of History, http://americanhistory.si.edu/victory/victory5.htm (accessed May 7, 2009). 
end the war and bring their men home-an convincing incentive for women to purchase war bonds.

Women responded to these advertisements by purchasing war bonds in large numbers. Mary Appling, a college student during the war, remembers that there were war bond sales at the high school she worked at. Appling remembers, "After several years I had amassed $\$ 1500$ worth of $\$ 25$ bonds, at $\$ 18.50$ per purchase. That was not a lot, but my salary was only about $\$ 1900$ yearly during the time." ${ }^{21}$ This shows that advertisements for war bonds were successful since women were going beyond setting aside saved money and putting the majority of their income towards the purchasing of war bonds. Not only were women tightening their purchasing habits, but they were able to supply the government with an emergency amount of revenue for the war.

War bonds were also advertised as a means for women to aid the success of the post-war economy by saving money for the household appliances that would become available after the war. Advertisements showed that if women cut down on consumption during the war in order to purchase war bonds it would not only result in a war victory, but would have a major impact on the post-war economy when women were able to purchase products for their homes again. Numerous advertisements displayed in Ladies' Home Journal and Good Housekeeping show how companies were targeting women to continue to buy and consume the products that were available to them, as well as to save money in anticipation for the products that would be available during peacetime. ${ }^{22}$ An advertisement for Emerson Electric home appliances stated, "The war bonds you buy today will pay for the new appliances and comfort conveniences you'll want after victory." ${ }^{23}$ The company encouraged women to save their money in order to buy war bonds that

${ }^{21}$ Mary L. Appling, "Behind the Combat," in Women of the Homefront: World War II Recollections of 55 Americans, ed. Pauline E. Parker (London: McFarland \& Company, Inc., 2002), 207.

22 Tawnya A. Covert, "Consumption and Citizenship during the Second World War: Product Advertising in Women's Magazines," Journal of Consumer Culture 3, no. 3 (November 2003): 326-328.

23 Emerson Electric Motors, Emerson Electric Company, Advertisement, Good Housekeeping, March 1944, 139. 
would not only help the current war effort, but would allow them to purchase the new technology available to them after the war. By purchasing new appliances and returning to their former consumption habits, housewives would be able to maintain their respected position after the war ended by improving the post-war economy.

Today the image of "Rosie the Riveter" is often revered as a symbol of the empowered women who served as heroines on the home front during World War II. However, a broader examination of the portrayal of women during World War II suggests that the housewife was more visibly depicted as a contributer to the fight for democracy overseas. Advertisements from the war also show that the dominant opinion of those in the advertising industry and government was that the homenot the workplace-was the proper place for American women. Advertisements frequently pictured housewives as the leading force behind the success of rationing policies, recycling efforts, and the purchasing of war bonds. Housewives were also viewed positively for their role as consumers, which made them crucial to aiding the post-war economy.

Taken together, these factors indicate a profound difference between present-day perceptions of "women on the home front" and the actual roles of women that were stressed during World War II. Though the wartime housewife is often overlooked today, she was the primary target for advertisements by the government and private corporations throughout the World War II period. Although advertisers were certainly influenced by financial motivations, the consequence of their work was an elevation of the domestic sphere, such that the American housewife was often portrayed as integral to the war's success in a manner that was both respectful and empowering. 


\section{BIBLIOGRAPHY}

Appling, Mary L. "Behind the Combat." In Women of the Homefront: World War II Recollections of 55 Americans, edited by Pauline E. Parker, 205-211. London: McFarland and Company, Inc., Publishers, 2002.

Barclay, McClelland. "Save Your Cans." Poster, U.S. War Production Board, 1943. The Ohio Historical Society. http://ohsweb.ohiohistory.org/ ohiopix/Image.cfm?ID=5020 (accessed November 24, 2009).

Belk, Russell W. and Richard W. Pollay. "Images of Ourselves: The Good Life in Twentieth Century Advertising." The Journal of Consumer Research 11, no. 4 (March 1985): 887-897.

Covert, Tawnya A. "Consumption and Citizenship during the Second World War: Product Advertising in Women's Magazines." Journal of Consumer Culture 3, no. 3 (Nov. 2003): 315-342.

Emerson Electric Motors. Emerson Electric Company. Advertisement. Good Housekeeping, March 1944.

Griffith, Robert. "The Selling of America: The Advertising Council and American Politics, 1942-1960." The Business History Review 57, no. 3 (Autumn 1983): 388-412.

"Her Seven Jobs Help Win the War," Swifts Brands of Beef. Advertisement. Good Housekeeping, January 1944.

Honey, Maureen. Creating Rosie the Riveter: Class, Gender, and Propaganda during World War II. Amherst: The University of Massachusetts Press, 1984. 
Lears, T.J. Jackson. "From Salvation to Self-Realization: Advertising and the Therapeutic Roots of the Consumer Culture, 1880-1930." In The Culture of Consumption: Critical Essays in American History, 1880-1980, edited by Richard Wightman Fox and T.J. Jackson Lears, 3-38. New York: Pantheon Books, 1983.

Leff, Mark H. "The Politics of Sacrifice on the American Home Front in World War II." The Journal of American History 77, no. 4 (March 1991): 1296-1318.

McFeely, Mary Drake. "The War in the Kitchen." In Produce and Conserve, Share and Play Square: The Grocer and the Consumer on the Home-Front Battlefield during World War II, 104-116.

Morris, John D. "Policing of the Food Front up to Housewife in the End." The New York Times, February 28, 1943.

Parker, Al. "We'll Have Lots to Eat This Winter, Won't We, Mother?" Poster, U.S. Office of War Information, 1943. The Smithsonian Institute's National Museum of American History. http://americanhistory.si.edu/ victory/victory5.htm (accessed November 23, 2009).

Produce and Conserve, Share and Play Square: The Grocer and the Consumer on the Home-Front during World War II. Edited by Barbara McLean. Hanover, NH: University Press of New England, 1994.

Sitkoff, Harvard. "The American Home Front." In Produce and Conserve, Share and Play Square: The Grocer and the Consumer on the Home-Front Battlefield during World War II, 36-56.

Sweets without Sugar cookbook. M.S. Mill Co., Inc. Advertisement. The New York Times, June 10, 1942.

Weatherford, Doris. American Women and World War II. New York: Facts on File, 1990. 
"What Women Can Do: Think War, Buy Little, Maintain Our Ideals." Life, September 28,1942, 32 .

Witowski, Terrence H. "World War II Poster Campaigns: Preaching Frugality to American Consumers." Journal of Advertising 32, no. 1 (Spring 2003): 69-82. 